\title{
A Review of Candidate Therapies for Beta Coronavirus a Molecular Research
}

\author{
Fatema Bassam Ahmed ${ }^{1,2}$, Aili Lyu ${ }^{3}$
}

${ }^{1}$ Xi'an Jiaotong University, Faculty of Nursing, China. ${ }^{2}$ Teacher Assistant, Tishreen University, Syria. ${ }^{3}$ Associate Professor, School of Nursing -Health Science Centre, Xi'an Jiaotong University, China.

\begin{abstract}
Coronavirus disease 2019 (COVID-19) is an infectious illness caused by the coronavirus 2 that causes severe acute respiratory illness (SARS-CoV-2). The first instance of this virus was reported on November $17^{\text {th }}, 2019$ in Wuhan, China. The COVID-19 outbreak is evidenced with devastating consequences such as $34.9 \%$ rate of mortality in 27 countries. The metastasizing of COVID-19 all over the world is alarmed to cause significant losses of human life, and for this there is no specific vaccination or therapy for COVID-19 in particular. The therapies suggested at this time are adapted from the treatments of Severe Acute Respiratory Syndrome (SARV-CoV). For instance, the development for a particular therapy or vaccination for COVID-19 is an urgent requirement. The pattern of study is based on investigating the research papers for the period of 2012-2020, identifying all the potential aspects of medical research contributing for the development of treatment against diverse families of coronavirus. By analyzing this approach, this study is aimed to provide a directed approach for developing appropriate therapy for COVID-19.
\end{abstract}

Keywords: Viral infection- COVID-19- therapies and vaccination- MERS-CoV- interferon- DPP4- betacoronavirus

Asian Pac J Cancer Care, 6 (Suppl 1), 83-86

\section{Introduction}

The molecular structure of coronavirus is an RNA virus incorporating about 27-32 KB positive-sense-singlestranded RNA [1]. The family origin of coronavirus is linked to Coronaviridae family that includes coronavirus diversification as alpha, beta, delta and gamma $[2,3]$. Classification of COVID-19 with respect to diversity of coronavirus origin was studies and investigated by taking sputum samples of oropharyngeal and nasopharyngeal swab, followed by real-time RT-PCR (Reverse Transcriptase-Polymerase Chain Reaction), virus isolation, construction of next generation sequencing (NGS) library of viral genome with full-length, followed by sequencing analysis and finally examined with transmission electron microscopy identified that new coronavirus SARS-CoV-2 (identified from COVID-19 disease, evidenced in Wuhan, China) as betacoronavirus [1].Moreover, the investigations for identifying the similarities and differences of SARS-CoV-2 with SARS$\mathrm{CoV}$ and MERS-CoV, it was found with not extreme
Submission Date: 06/07/2021 Acceptance Date: 08/17/2021

differences with respect to demographic characteristics, radiological and laboratory findings for MERS-CoV and SARS-CoV [4]. Therefore this paper examines the various approaches for treatment of SARS-CoV and MERS-CoV predicting a directive approach for developing COVID-19 vaccination.

\section{Methods}

This research is designed by carrying out thorough investigation of the previous researches for the period of 2012-2020, identifying the pathogenic investigation for coronavirus, and the analysis of antiviral treatments developed for coronavirus treatment during 2012 and 2015 coronavirus outbreak. For investigating the origin of SARS-CoV-2, the previous studies found the origin for MERS and SARS were evaluated.

\footnotetext{
Corresponding Author:

Ms. Fatema Bassam Ahmed

${ }^{1}$ Master Student, Xi' an Jiaotong University, Faculty of Nursing, China. ${ }^{2}$ Teacher Assistant, Tishreen University, Syria.

Email: fatema92w@gmail.com
} 


\section{Collected Data and its Analysis}

\section{Origin of Coronavirus}

MERS-CoV is enlisted in the zoonotic category found with origin from animals determining the main cause of its spread from physical contact with an infected animal $[5,6]$. In general, MERS-CoV was identified with its origin to dromedary camels [7], yet some other investigations found that genome of this virus is identified with its origin in bats that is suspected to be transmitted from bats (animal reservoir) to camels (intermediate host) $[5,8]$. The first identification of this virus was found in 2002 (identified as SARS), having its origin from bats (animal reservoir) and then to palm civets (as intermediate hosts) [4]. Then it was observed in 2012 in Saudi Arabia and in 2015 in Korea, and in the current time in 2019, in Wuhan [4]. For instance, SARS-CoV-2 is similar to MERS-CoV and SARS-CoV for demographical aspects and originating from bats, yet the intermediate host is still unknown [4].

\section{Transmission Mode}

The transmission mode for MERS-CoV was reported mainly with human-to-human interaction [8-10]. Moreover another study reported that $83 \%$ of the transmissions were observed with human-to-human contact, whereas $44 \%$ of cases were spread with nosocomial transmission [11], and the secondary mode (household contacts) of transmission is $4 \%$ [12]. For SARS-CoV-2 the investigations have identified a greater prevalence of virus replication, and hence causing considerably higher rate of its spread as compared to MERS-CoV and SARS-CoV [4].

\section{Causes of Infection}

Investigations identified that obesity, diabetes, cardiac malfunctioning, immune-compromised state, pulmonary disease as the risk factors of coronavirus [13, 14]. Also, the asymptomatic healthcare workers are observed with viral shedding at a delayed pace taking about 5 weeks, where not wearing masks or gloves potentially increases the chances of viral infection in the healthcare workers [15]. Moreover the people lying under old age group, and conditions involving comorbid situation are vulnerable to cause higher rate of coronavirus infection [16]. Also, diabetes mellitus (DM) and MERS-CoV were observed with a possible relationship as in 2012 outbreak, DM patients were found at increased risk for MERS-CoV severity [17-21] - whereas 2015 outbreak showed that coronavirus patients having lesser rate of DM, hence identifying an unclear relationship of DM with coronavirus infection [22-24].

\section{Analyzing Experimental Cases for Therapies and Vaccination}

A research examined the severity level of MERS-CoV, by selecting 17 patients during 2015 Korea outbreak there was the use of enzyme-linked immunosorbent assay for measuring levels of cytokine and chemokine serum by analyzing serial serums' samples [23]. The period of 18 days was the effervescence median time, indicating severe cases with extreme infiltrates of chest within one week of infection, and dyspnea was observed as soon as the first week of infection ended, gradually indicating visible symbols as second week of infection is started [23]. The group of patients with severe illness was found with with higher level as, whereas the and (serum levels) were observed with increment in the second week, such as versus and versus. This experiment implemented IFN- $\alpha$, and found no impact on the mild cases [23]. On the other hand, another study indentified the severity of disease by chest radiography [25]. Such as the diagram shows severe infection (A), and infection at mild level (B): (Figure 1).

Another study identified the therapy with combining ribavirin and IFN- $\alpha 2 \mathrm{a}$ is observed with increasing the survival expectancy of severe cases (versus) [26]. Another study examined the deficiency of IFN- $\beta 1 \mathrm{a}$, is expected to increase the severity of MERS-CoV infection, whereas ribarivin combination with IFN- $\alpha 2$ ais effective for treating MERS-CoV infection [16]. Also, the prophylactic and therapeutic interventions include monoclonal human antibodies targeting [27-29]. Moreover interferon treatment in vitro is a proposed treatment, including the encoding of elements for a greater number of genes allowing open-boundary evasions to the host's immune system, until high titers are established [30].

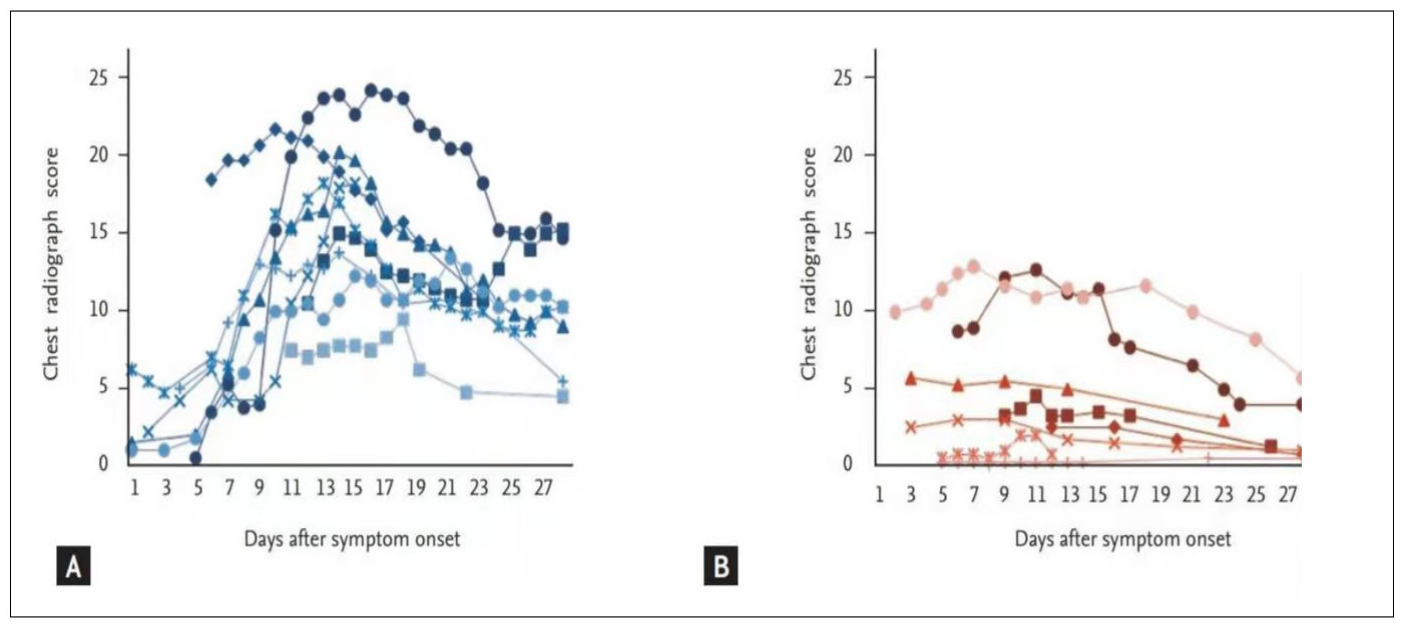

Figure 1. Chest Radiograph [25] 
Also, virus shedding, viral loads in lung tissues, hosts' gene expression with regulation, cytokines production and were observed during MERS-CoV infection [31]. Moreover another study examined that detectable antibodies found in the dead patients, the co-detection of antibodies with viral RNA can be utilized for developing therapeutics and vaccines [32]. Also, the role of IFN-I was examined, and demonstrated for clearing the virus and sustaining the survival of host during the infection - the study identified that virus replication and IFN-I response are critical aspects to identify the treatment and therapy for acute viral infections [33].

In conclusion, the current pandemic urges the important concern for realizing the pathogen capability for establishing and inducing infection in human with accordant clinical manifestations [34]. The natural response of the immune system for MERS-CoV and SARS-CoV evasion and lung pathology development according to viral attack are significant aspects to analyze the pathogenesis investigation of SARS-CoV-2 in humans.Since the laboratory features, radiology tests, and demogprahic characterstics of SARS-CoV-2 is similar to other coronaviruses [4], therefore(RT-PCR) can be consideredan efficient technique for estimating the rate of fatality by SARS-CoV-2 infection - moreover improving intensive care unit (ICU) services, timely monitoring for virus-specific antibodies neutralization, avoidance for complications are successful measures for recovery until an antiviral treatment is not proposed [35]. Other than this, IFN- $\alpha 2$ a or IFN- $\alpha$ combination with ribarivin, the role of IFN-I, and avoiding the deficiency of IFN- $\beta 1$ a are appropriate approaches can be tested against SARSCoV-2 treatment [16, 23, 33].

\section{Conflict of Interest}

The authors declare no conflict of information for this research.

\section{References}

1. Kim J, Chung Y, Jo HJ, Lee N, Kim MS, Woo SH, Park S, Kim JW, Kim HM, Han M. Identification of Coronavirus Isolated from a Patient in Korea with COVID-19. Osong Public Health and Research Perspectives. 202002 28;11(1):3-7. https://doi.org/10.24171/j.phrp.2020.11.1.02

2. Chan JF, To KK, Tse H, Jin D, Yuen K. Interspecies transmission and emergence of novel viruses: lessons from bats and birds. Trends in Microbiology. 2013 Oct;21(10):544-555. https:// doi.org/10.1016/j.tim.2013.05.005

3. Perlman S, Netland J. Coronaviruses post-SARS: update on replication and pathogenesis. Nature Reviews Microbiology. 200905 11;7(6):439-450. https://doi.org/10.1038/ nrmicro2 147

4. Petrosillo N, Viceconte G, Ergonul O, Ippolito G, Petersen E. COVID-19, SARS and MERS: are they closely related?. Clinical Microbiology and Infection. 2020 06;26(6):729734. https://doi.org/10.1016/j.cmi.2020.03.026

5. WHO. Middle East respiratory syndrome coronavirus (MERS-CoV) [Internet]. Who.int. 2019 [cited 2020 May 30]. Available from: https://www.who.int/news-room/ fact-sheets/detail/middle-east-respiratory-syndromecoronavirus-(mers-cov).
6. Zumla A, Hui DS, Perlman S. Middle East respiratory syndrome. The Lancet. 2015 09;386(9997):995-1007. https://doi.org/10.1016/s0140-6736(15)60454-8

7. Meyer B, Müller MA, Corman VM, Reusken CB, Ritz D, Godeke G, Lattwein E, Kallies S, Siemens A, van Beek J, Drexler JF, Muth D, Bosch B, Wernery U, Koopmans MP, Wernery R, Drosten C. Antibodies against MERS Coronavirus in Dromedary Camels, United Arab Emirates, 2003 and 2013. Emerging Infectious Diseases. 2014 04;20(4):552-559. https://doi.org/10.3201/eid2004.131746

8. Oboho IK, Tomczyk SM, Al-Asmari AM, Banjar AA, AlMugti H, Aloraini MS, Alkhaldi KZ, Almohammadi EL, Alraddadi BM, Gerber SI, Swerdlow DL, Watson JT, Madani TA. 2014 MERS-CoV Outbreak in Jeddah - A Link to Health Care Facilities. New England Journal of Medicine. 201502 26;372(9):846-854. https://doi.org/10.1056/ nejmoa1408636

9. Assiri A, McGeer A, Perl TM, Price CS, Al Rabeeah AA, Cummings DA, Alabdullatif ZN, Assad M, Almulhim A, Makhdoom H, Madani H, Alhakeem R, Al-Tawfiq JA, Cotten M, Watson SJ, Kellam P, Zumla AI, Memish ZA. Hospital Outbreak of Middle East Respiratory Syndrome Coronavirus. New England Journal of Medicine. 2013 08;369(5):407-416. https://doi.org/10.1056/nejmoa1306742

10. Memish ZA, Zumla AI, Al-Hakeem RF, Al-Rabeeah AA, Stephens GM. Family Cluster of Middle East Respiratory Syndrome Coronavirus Infections. New England Journal of Medicine. 201306 27;368(26):2487-2494. https://doi. org/10.1056/nejmoa1303729

11. Hui DS, Azhar EI, Kim Y, Memish ZA, Oh M, Zumla A. Middle East respiratory syndrome coronavirus: risk factors and determinants of primary, household, and nosocomial transmission. The Lancet Infectious Diseases. 2018 08;18(8):e217-e227. https://doi.org/10.1016/s14733099(18)30127-0

12. Drosten C, Meyer B, Müller MA, Corman VM, Al-Masri M, Hossain R, Madani H, Sieberg A, Bosch BJ, Lattwein E, Alhakeem RF, Assiri AM, Hajomar W, Albarrak AM, Al-Tawfiq JA, Zumla AI, Memish ZA. Transmission of MERS-Coronavirus in Household Contacts. New England Journal of Medicine. 201408 28;371(9):828-835. https:// doi.org/10.1056/nejmoa1405858

13. Alfaraj SH, Al-Tawfiq JA, Altuwaijri TA, Memish ZA. Middle East Respiratory Syndrome Coronavirus and Pulmonary Tuberculosis Coinfection: Implications for Infection Control. Intervirology. 2017;60(1-2):53-55. https:// doi.org/10.1159/000477908

14. Saad M, Omrani AS, Baig K, Bahloul A, Elzein F, Matin MA, Selim MA, Mutairi MA, Nakhli DA, Aidaroos AYA, Sherbeeni NA, Al-Khashan HI, Memish ZA, Albarrak AM. Clinical aspects and outcomes of 70 patients with Middle East respiratory syndrome coronavirus infection: a singlecenter experience in Saudi Arabia. International Journal of Infectious Diseases. 2014 Dec;29:301-306. https://doi. org/10.1016/j.ijid.2014.09.003

15. Al-Gethamy M, Corman VM, Hussain R, Al-Tawfiq JA, Drosten C, Memish ZA. A Case of Long-term Excretion and Subclinical Infection With Middle East Respiratory Syndrome Coronavirus in a Healthcare Worker. Clinical Infectious Diseases. 2014 Dec 16;60(6):973-974. https:// doi.org/10.1093/cid/ciu1135

16. Shalhoub S, Farahat F, Al-Jiffri A, Simhairi R, Shamma O, Siddiqi N, Mushtaq A. IFN- $\alpha 2$ a or IFN- $\beta 1$ a in combination with ribavirin to treat Middle East respiratory syndrome coronavirus pneumonia: a retrospective study. Journal of Antimicrobial Chemotherapy. 201504 21;70(7):2129-2132. 
https://doi.org/10.1093/jac/dkv085

17. Banik GR, Alqahtani AS, Booy R, Rashid H. Risk factors for severity and mortality in patients with MERS-CoV: Analysis of publicly available data from Saudi Arabia. Virologica Sinica. 201601 25;31(1):81-84. https://doi.org/10.1007/ s12250-015-3679-z

18. Badawi A, Ryoo SG. Prevalence of diabetes in the 2009 influenza $\mathrm{A}(\mathrm{H} 1 \mathrm{~N} 1)$ and the Middle East respiratory syndrome coronavirus: a systematic review and metaanalysis. Journal of Public Health Research. 2016 Dec 21;5(3). https://doi.org/10.4081/jphr.2016.733

19. International Diabetes Federation. IDF DIABETES ATLAS [Internet]. Diabetesatlas.org. 2019 [cited 2020 May 30]. Available from: https://diabetesatlas.org/upload/ resources/2019/2019_regional_factsheet.pdf.

20. Sabir JSM, Lam TTY, Ahmed MMM, Li L, Shen Y, E. M. Abo-Aba S, Qureshi MI, Abu-Zeid M, Zhang Y, Khiyami MA, Alharbi NS, Hajrah NH, Sabir MJ, Mutwakil MHZ, Kabli SA, Alsulaimany FAS, Obaid AY, Zhou B, Smith DK, Holmes EC, Zhu H, Guan Y. Co-circulation of three camel coronavirus species and recombination of MERS-CoVs in Saudi Arabia. Science. 2015 Dec 17;351(6268):81-84. https://doi.org/10.1126/science.aac8608

21. WHO. Diabetes country profile, Saudi Arabia [Internet]. 2017. Available from: https://www.who.int/diabetes/ country-profiles/sau_en.pdf.

22. Choi WS, Kang C, Kim Y, Choi J, Joh JS, Shin H, Kim G, Peck KR, Chung DR, Kim HO, Song SH, Kim YR, Sohn KM, Jung Y, Bang JH, Kim NJ, Lee KS, Jeong HW, Rhee J, Kim ES, Woo H, Oh WS, Huh K, Lee YH, Song JY, Lee J, Lee C, Kim B, Choi YH, Jeong SJ, Lee J, Yoon JH, Wi YM, Joung MK, Park SY, Lee SH, Jung S, Kim S, Lee JH, Lee H, Ki HK, Kim Y. Clinical Presentation and Outcomes of Middle East Respiratory Syndrome in the Republic of Korea. Infection \& Chemotherapy. 2016;48(2):118. https:// doi.org/10.3947/ic.2016.48.2.118

23. Kim ES, Choe PG, Park WB, Oh HS, Kim EJ, Nam EY, Na SH, Kim M, Song K, Bang JH, Park SW, Kim HB, Kim NJ, Oh M. Clinical Progression and Cytokine Profiles of Middle East Respiratory Syndrome Coronavirus Infection. Journal of Korean Medical Science. 2016;31(11):1717. https://doi. org/10.3346/jkms.2016.31.11.1717

24. Kim K, Tandi T, Choi J, Moon J, Kim M. Middle East respiratory syndrome coronavirus (MERS-CoV) outbreak in South Korea, 2015: epidemiology, characteristics and public health implications. Journal of Hospital Infection. 2017 02;95(2):207-213. https://doi.org/10.1016/j. jhin.2016.10.008

25. Oh M, Park WB, Park S, Choe PG, Bang JH, Song K, Kim ES, Kim HB, Kim NJ. Middle East respiratory syndrome: what we learned from the 2015 outbreak in the Republic of Korea. The Korean Journal of Internal Medicine. 201803 01;33(2):233-246. https://doi.org/10.3904/kjim.2018.031

26. Omrani AS, Saad MM, Baig K, Bahloul A, Abdul-Matin M, Alaidaroos AY, Almakhlafi GA, Albarrak MM, Memish ZA, Albarrak AM. Ribavirin and interferon alfa-2a for severe Middle East respiratory syndrome coronavirus infection: a retrospective cohort study. The Lancet Infectious Diseases. 2014 Nov; 14(11):1090-1095. https://doi.org/10.1016/s14733099(14)70920-x

27. Jiang L, Wang N, Zuo T, Shi X, Poon KV, Wu Y, Gao F, Li D, Wang R, Guo J, Fu L, Yuen K, Zheng B, Wang X, Zhang L. Potent Neutralization of MERS-CoV by Human Neutralizing Monoclonal Antibodies to the Viral Spike Glycoprotein. Science Translational Medicine. 201404 28;6(234):234ra59-234ra59. https://doi.org/10.1126/ scitranslmed.3008140
28. Lu L, Liu Q, Zhu Y, Chan K, Qin L, Li Y, Wang Q, Chan JF, Du L, Yu F, Ma C, Ye S, Yuen K, Zhang R, Jiang S. Structurebased discovery of Middle East respiratory syndrome coronavirus fusion inhibitor. Nature Communications. 2014 01 28;5(1). https://doi.org/10.1038/ncomms4067

29. Tang X, Agnihothram SS, Jiao Y, Stanhope J, Graham RL, Peterson EC, Avnir Y, Tallarico ASC, Sheehan J, Zhu Q, Baric RS, Marasco WA. Identification of human neutralizing antibodies against MERS-CoV and their role in virus adaptive evolution. Proceedings of the National Academy of Sciences. 201404 28;111(19):E2018-E2026. https://doi. org/10.1073/pnas.1402074111

30. Gralinski LE, Baric RS. Molecular pathology of emerging coronavirus infections. The Journal of Pathology. 2014 Dec 11;235(2):185-195. https://doi.org/10.1002/path.4454

31. de Wit E, Rasmussen AL, Falzarano D, Bushmaker T, Feldmann F, Brining DL, Fischer ER, Martellaro C, Okumura A, Chang J, Scott D, Benecke AG, Katze MG, Feldmann H, Munster VJ. Middle East respiratory syndrome coronavirus (MERS-CoV) causes transient lower respiratory tract infection in rhesus macaques. Proceedings of the National Academy of Sciences. 201309 23;110(41):1659816603. https://doi.org/10.1073/pnas.1310744110

32. Al-Abdely HM, Midgley CM, Alkhamis AM, Abedi GR, Lu X, Binder AM, Alanazi KH, Tamin A, Banjar WM, Lester S, Abdalla O, Dahl RM, Mohammed M, Trivedi S, Algarni HS, Sakthivel SK, Algwizani A, Bafaqeeh F, Alzahrani A, Alsharef AA, Alhakeem RF, Jokhdar HAA, Ghazal SS, Thornburg NJ, Erdman DD, Assiri AM, Watson JT, Gerber SI. Middle East Respiratory Syndrome Coronavirus Infection Dynamics and Antibody Responses among Clinically Diverse Patients, Saudi Arabia. Emerging Infectious Diseases. 2019 04;25(4):753-766. https://doi. org/10.3201/eid2504.181595

33. Channappanavar R, Fehr AR, Zheng J, Wohlford-Lenane C, Abrahante JE, Mack M, Sompallae R, McCray PB, Meyerholz DK, Perlman S. IFN-I response timing relative to virus replication determines MERS coronavirus infection outcomes. Journal of Clinical Investigation. 201907 29;129(9):3625-3639. https://doi.org/10.1172/jci126363

34. Kolifarhood G, Aghaali M, Mozafar Saadati H, Taherpour N, Rahimi S, Izadi N, et al. Epidemiological and Clinical Aspects of COVID-19; a Narrative Review. Arch Acad Emerg Med. 2020 Apr 1;8(1). PMID PMID: 32259130; PMCID: PMC7117787

35. Public Health England. Treatment of MERS-CoV: Information for Clinicians Clinical decision-making support for treatment of MERS-CoV patients [Internet]. PHE Publications; 2017. Available from: https://assets.publishing. service.gov.uk/government/uploads/system/uploads/ attachment_data/file/638628/MERS_CoV_guidance_for_ clinicians.pdf.

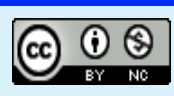

This work is licensed under a Creative Commons AttributionNon Commercial 4.0 International License. 